\title{
Implementation of Government Regulation Number 11 of 2017 in The Making Transparency Candidate Recruitment of Civil Servants in Custody in The Formation of Position Guard Regional Office Ministry of Justice And Human Rights of Central Java
}

\author{
Pudyastuti Kusuma Wardhani ${ }^{1}$
}

Abstract. Implementation of Recruitment CPNS ideal and transparent according to Regulation No. 11 Of 2017 is the presence of Planning Phase Phase Announcement Jobs Stage Applying Stage Selection Selection Result Announcement. Best Criteria for Carers Formation Resistivity employess employess must have a stock that is as well able to practice martial rules are rules which should not be violated in accordance with Government Regulation No. 11 of 2017 on Civil Service Management. Recruitment obstacles in the implementation employess employess are determining criteria to be spelled out in the system of administration of an application the Selection CAT whose implementation in BKN only have a few units of computers alone is not proportional to the number of applicants who apply,Physical criteria employess formation detainee guards should be done by the competent authorities Observation Physical and skills tested by the examiner should be done by an expert interview. Efforts are being made in resolving these obstacles are Selection of administration should be carried out independently with the online system by providing value criteria that are not limited to academic Exams CAT is done online with the preparation by the recipient employees ooportunity should be tested by the parties who have expertise in physical testing and competent to do so Implementation does not have Standard Operating (SOP) that is in determining the best criteria for the formation of candidates for Civil Servants guard prisoners.

Keywords: Employess Recruitment Guard Prisoner.

\section{Introduction}

To achieve national goals required the State Civil servants Apparatus (ASN). ASN employee was assigned to perform public service tasks the tasks of government and certain development tasks. Public service tasks performed by providing services for goods services and / or administrative services provided Employees ASN. Formation procurement and appointment is a series of activities that are essential to the existence of a Civil Servant. The Basic Law on Civil Servants formations that Act No. 5 of 2014 on State Civil Apparatus whereas implementation instructions Indonesian Government Regulation No. 11 of 2017 on the Civil Service Management Chapter III Procurement. Correctional officers are the Civil Service under the Ministry of Justice and Human Rights whose primary task is to monitor and maintain the safety security and order of the prisoners who are in prison or State Prison. The problem today is the ratio between the number of correctional officer with the detainee or convict both

\footnotetext{
${ }^{1}$ Student of Masters (S2) of Law Faculty of Law Unissula and State Civil servants Apparatus email: dhanie.kumham2010@gmail.com
} 
Penitentiary and Prison State is striking. Overcapacity problem not be the only trigger frequent riots or escaped prisoners. The problem today is the ratio between the number of correctional officer with the detainee or convict both Penitentiary and Prison State is striking. Overcapacity problem is not the sole trigger frequent riots or escaped prisoners. The problem today is the ratio between the number of correctional officer with the detainee or convict both Penitentiary and Prison State is striking. Overcapacity problem not be the only trigger frequent riots or escaped prisoners.

Based on the description above the problem can be formulated as follows: How is the implementation of an ideal civil servant recruitment and transparent according to Government Regulation No. 11 of 2017 at the Regional Office of the Ministry of Justice and Human Rights in Central Java?; What are the barriers and efforts by the Regional Office of the Ministry of Justice and Human Rights in Central Java in the implementation of civil servant recruitment Guard Position Formation Resistivity?

\section{Research methods}

The method used in this study is the method of juridical empirical approach (sociological jurisdiction). Specifications used in this research is descriptive analysis that is what is stated by the respondent in writing and orally and also the real behavior who researched and studied as a whole. ${ }^{2}$ Data required in this study are: 1) Primery data. This data is the data obtained directly from the object of research. In this case the primary data obtained by conducting interviews; 2 ) The secondary data this data is data obtained through research of literature both book and legislation relating to the theme of writing

\section{Results and Discussion}

\subsection{Implementation of Ideal Employess Recruitment and Transparent According to Government Regulation No. 11 of 2017 at the Regional Office of the Ministry of Justice and Human Rights in Central Java}

Based on the interview with the author of Head of Sub Division Officer and TU in the Regional Office of the Ministry of Law and Human Rights in Central Java as the Secretary of the Regional Committee for Selection of Civil Servants at the Regional Office of the Ministry of Justice and Human Rights in Central Java Budget Of 2017 can be described as follows ${ }^{3}$ :

\subsubsection{Stage Planning and Coordination with Related Parties}

The Ministry of Justice and Human Rights in this case the Civil Service Bureau of the General Secretariat of the Ministry of Justice and Human Rights as the Central Committee has made advance planning as planning the necessary budget planning the number of formations of employees needed by analyzing the need for employees to get the number of formations guard prisoners the right and according to the needs

\footnotetext{
${ }^{2}$ Soerjono Soekanto 2005 Pengantar Penelitian Hukum,Universitas Indonesia Press Jakarta p. 250

3 Interview with Mr. Budhiarsoo Widhyarsono Head of Sub Division Officer and TU Central Java Kemenkumham Regional Office October 22017
} 
institutions the establishment of civil servant selection committee schedule planning and execution activities employess planning yag infrastructure needs to be used everything was already planned.

\subsubsection{Phase Vacancy Announcement}

The Ministry of Justice and Human Rights announced the official announcement CPNS Selection Procurement of 2017 through the official website and the site

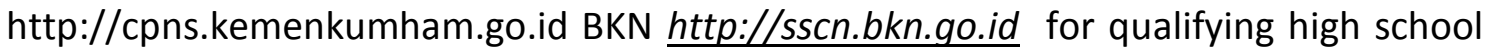
education / equivalent with the formation of Detention Guard positions which would be opened by the society at large.

\subsubsection{Applying}

Based on the interview with the author of one of the applicants who have passed the civil servant named Yossa Bimara Selection Restuaji that applicants must apply through online sites to enter data BKN http://sscn.bkn.go.id NIK to log in. Once the registration process is complete applicants get a printed proof of registration for use in the validation process documents in the agency and the applicant submitting the necessary application file.

\subsubsection{Selection}

Selection is divided into two (2) that the selection and implementation schedule stage the stage of selection to Schedule Selection can be done through the page https://sscn.bkn.go.id which is an online application developed and under the control of the State civil service Agency (BKN) used in the stage of registration until the card printing examinees employess. While Stages Selections include: Selection of Administrative Verification File at PO BOX Original File Selection Verification Administration and Measurement Height Sector Competency Selection (LCS) through opportunity Sector Competency Selection Through Physical Observations.

\subsubsection{Selection Results Announcement}

The results of the selection announcement given to those who have passed the final stage by holding rank number is strictly limited in the number of civil service candidates needed. Participants Prospective Civil Servants can see the results announcement through the website which has been determined thathttp://cpns.kemenkumham.go.idor on the official website of the State Employment Agency and the Ministry of Administrative Reforms and Civil State. In the announcement not only list the number and names of participants alone but the result of the acquisition value of the initial stage of selection (CAT) to the value of opportunity and Observations Physical and Skills.

2.2. Barriers and Efforts Conducted by the Regional Office of the Ministry of Justice and Human Rights in Central Java in Implementing Civil Servant Recruitment Candidates of Guard Position Formation Resistivity 
Obstacles in the implementation of the civil servant recruitment among others:

- Determination of criteria for candidates for Civil Servants should be spelled out in the system of administration of an application which must then be submitted by each applicant labor where both the admnisitrasi system will be able to reflect things that are desirable from a civil servant;

- In the exam Computer Assessment Base (CAT) held at BKN some things still make the barriers namely when BKN give exam only have a few computers and implementation of these exams must be done online so it takes a small cost considering the participants who qualify in the selection and administration at the Regional Office of the Ministry of Justice and Human rights in Central Java for the formation Guard Detainees as many as 724 people and the implementation of the exam should be done within a period of 5 (five) working days.

- Determining the best criteria are also carried out during the exam opportunity where the criteria for physical from a CPNS formation guard prisoners should be carried out by the competent authorities namely the police in this case BRIMOB physical observations should be made directly to any candidate who has passed the test PAINT. The number of participants who took the exam opportunity in the Regional Office of the Ministry of Justice and Human Rights in Central Javaas many as 2,178 people. However this physical assessment must also be passed by the limitations of time and understaffed team of testers so the perceived physical assessment is not maximized.

- as well as the interview system has shortcomings that a lack of capacity and expertise an interviewer in studying and understanding the answers and the intent of the questions it should be able to attract a person in accordance with the desired criteria. Interviewer interviewing do not go into the system like a psychiatrist when interviewing the job.

Efforts to resolve these barriers include:

- Selection of administration should be carried out independently with the online system by providing value criteria that are not limited to the academic but also there are specific points to a skill possessed by each applicant.

- Computer exam Assessment Test (CAT) conducted online with the preparation by the recipient employees so there were no obstacles such as the place the network and the tools used.

- Opportunity or physical ability should be tested by the parties who have expertise in physical testing and competent to do so as a doctor or physical fitness trainer so physical is not only determined by how well a person in the exercise.

- The Ministry of Justice and Human Rights as a civil servant recruitment organizers do not have a detention guard formation Operational Standards Implementation (SOP) that is in determining the best criteria for the formation of candidates for Civil Servants guard prisoners. Participants employess who have passed the selection process was not followed by education first Correctional Officer should have the specific tasks and special training before plunging into the world of work they see themselves not be directly placed as a guard officer arrested after passing the selection. 
- Physical observations and Skills (Interview) should be done by experts who could do interviews and certified so the questioning can describe the ability of a person as a whole not just limited to the keywords specified by the center.

\section{Closing}

\subsection{Conclution}

- Implementation of employess Ideal Recruitment and Transparent According to Government Regulation No. 11 of 2017 at the Regional Office of the Ministry of Justice and Human Rights in Central Java begins with determining the criteria employees needed the determination of the amount nature and type of employees to be received followed by the selection and placement with the necessary competence in the work so that recruitment is conducted in accordance with their needs. Furthermore the compensation required by each employee this is provided through salaries and benefits both performance benefits and other employment benefits that are tailored to each type of job. Each employee also must be given training and development in accordance with the job do analysis by the management office. After being given the training and development of each employee's performance appraisal should also be given in order to determine the level of employee performance.

- Barriers and determine the efforts made by the Regional Office of the Ministry of Justice and Human Rights in Central Java in the implementation of recruitment civil servant position formations guard prisoners shortcomings and obstacles encountered along the activities of the determination of the criteria employess up to the amount of the employee formation and also the selection made can be overcome by the same efforts with each other so there is no significant gap in the face of obstacles exist.

\subsection{Suggestion}

- Selection of administration should be carried out independently with the online system by providing value criteria that are not limited to the academic but also there are specific points to a skill possessed by each applicant. In addition it is not limited by domicile acceptance so that every citizen of Indonesia everywhere the same opportunity to enroll in the desired spot.

- Computer exam Assessment Test (CAT) conducted online with the preparation by the recipient employees so there were no obstacles such as the place the network and the tools used.

- Opportunity or physical ability should be tested by the parties who have expertise in physical testing and competent to do so as a doctor or physical fitness trainer so physical is not only determined by how well a person in the exercise.

- Until now the Ministry of Justice and Human Rights as a civil servant recruitment organizers do not have a detention guard formation Operational Standards Implementation (SOP) that is in determining the best criteria for the formation of candidates for Civil Servants guard prisoners. Participants employess who have passed the selection process was not followed by education first Correctional Officer 
should have the specific tasks and special training before plunging into the world of work they see themselves not be directly placed as a guard officer arrested after passing the selection.

- Physical observations and Skills (Interview) should be done by experts who could do interviews and certified so the questioning can describe the ability of a person as a whole not just limited to the keywords specified by the center.

\section{References}

[1] Daniri 2006 Konsep dan Penerapan Good Coorporate Governance Dalam Konteks Indonesia Ray Indonesia,Jakarta

[2] Soekanto Soerjono 2005 Pengantar Penelitian Hukum,Universitas Indonesia Press Jakarta.

[3] Act No. 5 of 2014 on State Civil Apparatus

[4] Government Regulation No. 11 of 2017 on the Civil Service Management 2017.

[5] RI State Secretariat 2014 Act No. 5 of 2014 concerning the State Civil Apparatus Jakarta.

[6] Regulation of the Minister of Justice and Human Rights 2010 Number: MHH05.OT.01.01 Of 2010 on the functions of the Ministry of Law and Human Rights in Jakarta.

[7] Head BAKN Circular No.04 / SE / 1976 on the formation of civil servants drafting instructions 1976

[8] Directorate General of Corrections 2013 Guidelines for Development of Personality Prisoners For Officers in prison / detention Jakarta.

[9] Interview with Mr. Budhiarsoo Widhyarsono Head of Sub Division Officer and TU Central Java Kemenkumham Regional Office October 22017 